\title{
ADJEKTIVA BERMAKNA RUANG DALAM BAHASA RUSIA
}

\author{
Tri Yulianty Karyaningsih \\ Fakultas Ilmu Budaya Universitas Padjadjaran \\ t.yulianty@unpad.ac.id \\ Trisna Gumilar \\ Fakultas Ilmu Budaya Universitas Padjadjaran \\ trisna.gumilar@unpad.ac.id
}

\begin{abstract}
Abstrak
Dalam bahasa Rusia terdapat adjektiva yang menyatakan makna ruang atau tempat, yakni berupa lokasi dan arah. Adjektiva demikian berbeda secara morfologis, sintaktis, dan semantis dengan adjektiva kualitatif biasa. Untuk itu, dalam artikel ini dibahas mengenai perilaku morfologis, sintaktis, dan semantisadjektiva bermakna ruang dalam bahasa Rusia. Metode yang digunakan dalam penelitian ini adalah metode deskriptif dengan model analisis morfologis, sintaktis, dan semantis. Data berupa adjektiva bermakna ruang berasal dari buku-buku gramatika, sementara data analisis berupa kalimat diambil dari korpus nasional bahasa Rusia. Hasil penelitian menunjukkan bahwa adjektiva bermakna ruang merupakan adjektiva derivatif yang dibentuk dari nomina dan adverbia secara morfologis melalui afiksasi dan pembubuhan fleksi pemarkah adjektiva. Secara semantis, makna ruang pada adjektiva ditunjukkan oleh kata pembentuknya, yakni nomina dan adverbia bermakna tempat, serta prefiks pada adjektiva denominal. Adapun secara sintaktis, adjektiva ini umumnya bersifat atributif.
\end{abstract}

Kata kunci: adjektiva, makna ruang, lokasi, arah, bahasa Rusia

\begin{abstract}
In Russian there are adjectives with the space meaning, which state location and direction. These adjectives differ morphologically, syntactically, and semantically with qualitative adjectives. Therefore, this article discusses the morphological, syntactic, and semantic behavior of the adjectives with the space meaning. The method used in this research is descriptive method with morphological, syntactic, and semantic analysis models. Data are taken from Russian grammar books and from the national corpus of Russian language. The results showed that the adjectives with the space meaning are derivative form which is formed from nouns and adverbs through affixation and addition of the adjectives inflexion. Semantically, the space meaning of these derivative adjectives is shown by nouns and adverbs with the meaning of places as its constituent elements. The space meaning in adjectives is also came from prefixes on the de-nominal adjectives. Syntactically, these adjectives are generally used as attribute.
\end{abstract}

Keywords: adjectives, space meaning, location, direction, Russian language

\section{PENDAHULUAN}

Adjektiva merupakan kategori atau kelas kata yang dapat ditemui pada banyak bahasa dan umumnya didefinisikan sebagai kelompok kata yang 
menyatakan keadaan bukan berupa proses, tetapi keadaan berupa ciri atau sifat suatu benda. Pada umumnya, ciri atau sifat tersebut menyatakan kualitas secara langsung, tetapi dalam bahasa Rusia, di samping itu terdapat adjektiva yang menyatakan makna ruang atau prostanstvennoe znacenie (Belousov, et al, 1989: 95, 96), yakni menyatakan tempat atau lokasi, posisi, kedudukan, keberadaan, serta menyatakan arah ke atau dari suatu tempat. Sebagai contoh, pada frasa gorodskij transport 'transportasi kota', gorodskij 'kota' berkategori adjektiva yang pada frasa tersebut menyatakan makna tempat, sehingga frasa tersebut dapat memiliki arti transportasi yang (ada) di kota. Contoh lain, zagorodnyj merupakan adjektiva yang dibentuk dari nomina gorod 'kota' dengan penambahan prefiks $z a$ - dan sufiks $-n-$, serta fleksi adjektival $-y j$. Prefiks $z a$ - pada adjektiva tersebut memberikan nuansa makna tempat, yakni yang diletakkan atau berada di seberang. Oleh karena itu, adjektiva zagorodnyj bermakna 'yang (ada atau terletak) di seberang kota'.

Pada dua contoh adjektiva di atas tampak bahwa makna ruang pada adjektiva bahasa Rusia diwujudkan secara leksikal melalui makna dasar kata pembentuknya atau dengan bantuan afiks (prefiks). Tampak pula bahwa adjektiva tersebut bukan merupakan adjektiva yang menyatakan keadaan atau kualitas berupa sifat atau ciri secara langsung, tetapi sifat atau ciri berupa lokasi ini dinyatakan melalui kategori lain, yakni nomina. Hal ini dapat dipahami karena dalam bahasa Rusia, adjektiva dibedakan atas tiga tipe, yaitu adjektiva kualitatif 'kacestvennye prilagatel'nye', adjektiva relatif 'otnositel'nye prilagatel'nye', dan adjektiva posesif 'pritjažatel'nye prilagatel'nye', sebagaimana umumnya dikemukakan para linguis Rusia seperti Dudnikov, Arbuzova, Vorozhbitskaya (2001: 113) serta Maksimov, et al (2010: 482-485). Adjektiva kualitatif merupakan adjektiva yang langsung menyatakan ciri/sifat seperti ciri fisik, mental, ukuran, warna, jarak, suhu, rasa; sementara adjektiva relatif menunjukkan ciri melalui relasinya dengan benda atau gejala yang antara lain menyatakan materi pembuat, tempat, waktu, orang atau kegiatan yang menjadi sasaran (Kalinina \& Anikina, 1975, dalam Karyaningsih, 2018b: 4), dan tidak dapat digunakan untuk menyatakan pertarafan. Adapun adjektiva posesif yang disebut sebagai varian dari adjektiva relatif oleh Dudnikov, et al (2001: 129), adalah adjektiva yang menyatakan kepemilikan benda oleh orang atau hewan (dalam Karyaningsih, 2018b: 4).

Berdasarkan paparan di atas, adjektiva bermakna ruang yang merupakan adjektiva derivatif, yakni berasal dari kategori atau kelas kata lain, yang melalui kategori tersebut diungkapkan keadaan berupa ciri, sehingga dapat dikatakan bahwa adjektiva ini merupakan adjektiva tipe relatif. Hal ini juga sesuai dengan pernyataan Dudnikov, et al (2001: 123) mengenai salah satu makna yang disandang adjektiva relatif, yakni makna ruang. Makna ruang berupa lokasi dan arah pada adjektiva ini dibentukmelalui sufiksasi dan pembubuhan fleksi pemarkah adjektiva pada kata pembentuknya, seperti kata gorodskij di atas yang dibentuk dari nomina gorod 'kota' dan penambahan sufiks -sk- serta fleksi adjektival -ij sebagai pemarkah kategori gramatikal gender maskulin, jumlah tunggal, dan kasus nominatif. Selain nomina, kata pembentuk adjektiva bermakna ruang ini dapat berupa adverbia yang secara semantis menyatakan makna tempat, seperti zdešnji '(yang) di sini' yang dibentuk dari zdes' 'di sini', 
tamošnij '(yang) di sana' yang berasal dari tam 'di sana' (Belousov, et al, 1989: 93 94).

Dalam pembicaraan mengenai pembentukan kata pada adjektiva, Walgina, Rozental', dan Fomina (2002) mengemukakan afiks-afiks yang digunakan dalam pembentukan adjektiva ini. Di antara afiks-afiks tersebut, terdapat afiks yang memberikan nuansa makna lokatif. Dalam Akademija Nauk SSSR (TT) dan Belousov, et al (1989: 96-98), makna lokatif ini ada pada pembentukan adjektiva dengan cara prefiksasi dan konfiksasi (prefiks + sufiks). Berbedanya cara afiksasipada pembentukan adjektiva ini berkaitan dengan proses pembubuhan afiks tersebut, yakni pada prefiksasi, prefiks hanya dibubuhkan pada adjektiva sebagai dasar kata pembentuknya; sementara pada proses konfiksasi, prefiks dan sufiks ditambahkan secara bersamaan pada dasar kata pembentuk adjektiva, yaitu nomina. Namun demikian, makna ruang pada adjektiva derivatifini pada dasarnya berasal dari prefiks, sebagaimana pada contoh di atas, zagorodnyj. Makna ruang yang menyatakan lokasi, posisi, atau keberadaan 'di seberang' pada adjektiva tersebut berasal dari prefiks $z a$ - yang secara semantis antara lain mengandung makna 'di seberang'.

Secara sintaktis, adjektiva dapat berfungsi atributif dan predikatif, tetapi fungsi utama adjektiva adalah membentuk konstruksi atributif (Sinkevich, 2010: 241), yang dapat dilihat pada adanya konkordansi dalam kategori gramatikal gender, jumlah, dan kasus antara adjektiva dengan nomina dalam suatu relasi atributif (dalam Karyaningsih, 2018a: 22). Jenis adjektiva relatif ini umumnya berfungsi atributif, yakni memberikan keterangan sebagai ciri terhadap suatu benda .Oleh sebab itu pula, adjektiva relatif ini umumnya digunakan dalam suatu konstruksi frasa nomina. Karena adjektiva bermakna ruang ini termasuk ke dalam tipe adjektiva relatif, maka adjektiva bermakna ruang inipun umumnya jarang digunakan dalam suatu konstruksi predikasi. Artinya, adjektiva bermakna ruang ini tidak menjadi unsur predikat dalam suatu konstruksi kalimat. Namun demikian, adjektiva relatif dalam suatu konstruksi frasa nomina dapat memiliki bentuk sinonimnya. Mengambil contoh di atas, frasa nomina gorodskij transport 'transportasi kota' bersinonim dengan frasa beratribut frasa preposisional, yakni transport $v$ gorode 'trasportasi di kota'. Begitu pula dengan adjektiva zagorodnyj '(yang) di seberang kota' yang bersinonim dengan frasa preposisional za gorodom 'di seberang kota'. Sharipova (2007: 110) menyebut dua konstruksi sinonim ini sebagai konstruksi atributif yang korelatif. Bahkan secara generatif melalui penelusuran struktur dalamnya (deep structure), Sharipova (2007: 111) memandang konstruksi seperti gorodskij transport pada dasarnya merupakan kompresi dari konstruksi transport $v$ gorode yang berproses dari konstruksi transport, kotoryj byvaet v gorode 'transportasi yang ada di kota' dan bermula dari konstruksi predikatif $V$ gorode byvaet transport 'Di kota ada (alat) transportasi'. Kondisi konstruksi demikian disebutnya sebagai predikasi tersembunyi dalam struktur atributif. Walaupun hal ini menuai kritik, tetapi Sharipova (2007: 111) melihat fakta adanya konstruksi atributif yang biasa digunakan dalam gaya bahasa buku dan literatur atau dalam bahasa tulis, 
sementara dalam gaya bahasa lisan/percakapan lebih sering digunakan konstruksi predikatif.

Pada buku-buku gramatika bahasa Rusia, adjektiva bermakna ruang tidak dibicarakan secara khusus, tetapi hanya disinggung pada pembicaraan mengenai makna-makna yang dinyatakan adjektiva relatif seperti makna bahan, waktu, peruntukan, cara, dan sebagainya. Begitu pula dengan berbagai nuansa makna ruang yang berasal dari prefiks, yang secara umum dibicarakan pada cara pembentukan adjektiva. Oleh sebab itu, menarik untuk dibicarakan secara khusus dan terpisah mengenai makna ruang yang disandang oleh adjektiva dalam bahasa Rusia ini, yang secara morfologis, sintaktis, dan semantis menunjukkan kekhususan. Tiga hal tersebut, yakni perilaku morfologis, sintaktis, dan semantis, merupakan tiga kriteria yang cukup memperjelas ciri adjektiva dalam bahasa Rusia, sebagaimana dikemukakan Miletova (2008: 196).

\section{METODE PENELITIAN}

Metode yang digunakan dalam penelitian ini adalah metode penelitian deskriptif dengan metode kajian distribusional, yaitu unsur bahasa itu sendiri atau bahasa yang diteliti menjadi alat penentunya (Djajasudarma, 1993: 60). Melalui teknik catat, data berupa adjektiva bermakna ruang dirujuk dari bukubuku gramatika bahasa Rusia. Data berupa adjektiva tersebut kemudian dicari dalam korpus nasional bahasa Rusia yang diakses melalui situs www.ruscorpora.ru sehingga didapatkan kalimat yang di dalamnya mengandung adjektiva bermakna ruang tersebut. Data berupa kalimat ini lah yang disajikan dalam analisis data. Data terjaring ini kemudian dipilah berdasarkan perilaku morfologis dan semantisnya, yakni melalui kata dasar pembentuk serta afiks berikut makna leksikal dasar atau gramatikalnya.

Pada tahap analisis data dilakukan teknik dasar bagi unsur langsung (Sudaryanto, 2015: 37). Pada analisis morfologis terkait proses pembetukan adjektiva bermakna ruang, dilakukan dengan membagi unsur-unsur pembentuk langsung adjektiva, yakni kategori kata sebagai dasar pembentuknya, serta afiks berupa sufiks dan prefiks, kemudian fleksi pemarkah adjektiva. Begitu pula pada analisis sintaktis terkait fungsi atributif adjektiva pada suatu frasa dalam kalimat atau fungsi predikatif dalam suatu kalimat.Teknik baca markah juga diterapkan untuk melihat pemarkah kategori gramatikal gender, jumlah, dan kasus yang disandang adjektiva atributif bermakna ruang. Kategori gramatikal ini merupakan ciri morfologis adjektiva, yang pada suatu konstruksi frasa, kategori gramatikal inidapat membentuk relasi konkordansi di antara adjektiva dengan nomina yang diatributinya. Analisis semantis dilakukan terkait dengan makna unsur-unsur pembentuk adjektiva, yakni makna leksikal dasar kategori dan prefiks pembentuk adjektiva. Pada tahap ini juga diterapkan teknik lanjutan

parafrasa, yakni melalui pengubahan wujud, yang dilakukan untuk memperjelas atau menguji makna ruang yang disandang adjektiva derivatif ini.

\section{HASIL DAN PEMBAHASAN}

Berikut pembahasan mengenai adjektiva yang menyatakan makna ruang dalam bahasa Rusia dengan mengacu pada uraian di atas serta data terjaring sebagai pendukungnya. Pembahasan dipilah berdasarkan kategori pembentuk 
adjektiva serta afiks berupa prefix yang dibubuhkan pada pembentuk adjektiva ini.

\subsection{Adjektiva Denominal Bermakna Leksikal Dasar Ruang}

Adjektiva bermakna ruang dapat diungkapkan oleh adjektiva yang dibentuk dari nomina atau adjektiva denominal melalui penambahan sufiks pembentuk adjektiva serta pembubuhan fleksi pemarkah adjektiva, seperti tampak pada data berikut.

1) Eto byl, kak ja potom vyjasnil, moskovskijpoet Dmitrij itu adalah seperti saya kemudian mencari tahu Moskow penyair Dmitri

Adj.m.t.nom N.m.t.nom

Kuz'min . (Zapis' Live Journal. 2004. Dalam Korpus Nasional Bahasa Rusia) Kuzmin

'Itu, seperti yang kemudian saya ketahui, adalah penyair (dari)

Moskow, Dmitri Kuzmin.'

2) Na nekotoroye vremya sredoj ego obitanija stanet avstralijskaja tjur'ma.

pada beberapa waktu habitat dia menjadi Australia penjara

Adj.f.t.nom

N.f.t.nom

(Nositel' Cuzhoj Žizni. Kriminal'naja Hronika. 2003.07.08. Dalam Korpus Nasional Bahasa Rusia)

'Untuk beberapa waktu, yang akan menjadi habitatnya adalah penjara Australia.'

3) Meždu tem korotkoye severnoe leto uzhe zakanchivalos'.

Di antara itu pendek utara musim panas telah berakhir

\section{Adj.n.t.nom N.n.t.nom}

(Yevgeni Vodolazkin.Lavr. 2012. Dalam Korpus Nasional Bahasa Rusia)

'Sementara itu, musim panas yang pendek di utara telah berakhir.'

Pada kalimat data (1) sampai dengan (3) terdapat adjektiva bermakna ruang, yakni moskovskij, avstralijskaja, dan severnoe, yang masing-masing dibentuk dari dasar nomina Moskva '(kota) Moskow', Avstralija 'Australia', dan sever 'utara' dengan penambahan sufiks -sk-dan -n- serta fleksi adjektival -ij, -aja, dan -oe sebagai pengungkap ciri morfologis berupa kategori gramatikal gender, jumlah, dan kasus. Kategori gramatikal ini menunjukkan adanya relasi konkordansi dengan nomina yang diatributinya, yaitu poet 'penyair' pada (1), tjurma 'penjara' pada (2), dan leto 'musim panas' pada (3), sebagaimana dapat dilihat pada pemarkah-pemarkah linguistis yang tercantum di bawah ketiga frasa tersebut. Hal ini menunjukkan fungsi yang disandang adjektiva tersebut, yakni sebagai atribut dalam konstruksi frasa. Melalui parafrasa, makna ruang bersifat lokatif dan direktif ini dapat dipahami dengan jelas, yaitu penyair yang (berasal) dari Moskow, penjara yang (ada) di Australia, dan musim panas yang (terjadi) di wilayah utara. Makna ruang ini diperjelas pula oleh nomina 
pembentuk ketiga adjektiva di atas, yang secara semantismengandung makna leksikal dasar lokatif atau tempat, yakni berupa nama kota, negara, dan arah mata angin.

\subsection{Adjektiva Deadverbial Bermakna Leksikal Dasar Ruang}

Salah satu makna yang dapat diungkapkan adverbia dalam bahasa Rusia adalah makna lokatif. Oleh karena itu, adjektiva yang dibentuk dari adverbia atau adjektiva deadverbial ini dapat menyatakan makna ruang berupa lokasi atau arah. Seperti pada adjektiva denominal, pada adjektiva deadverbial pun ditambahkan sufiks pembentuk adjektiva disertai pembubuhan fleksi pemarkah adjektiva. Berikut contoh data adjektiva deadverbial ini.

4) Kogda tam ošnij pravitel' vyšel k nim, ego ubili.

ketika di sana penguasa datang ke mereka dia dibunuh

Adj.m.t.nom N.m.t.nom

(A. Alekseev. Vikingi, Varyagi, Rus'. Nauka i Žizn'.2008 . Dalam Korpus Nasional Bahasa Rusia)

'Ketika penguasadi sana datang menemui mereka, mereka membunuhnya.'

5) Naverno, znaet. On zdešnij. (Vasil' Bykov. Boloto. 2001. Dalam Korpus Nasional

Mungkin tahu dia di sini Bahasa Rusia)

Adj.m.t.nom

'Mungkin dia tahu. Dia di sini.'

Pada kalimat data (4) dan (5),tamošnij dan zdešnij adalah adjektiva yang dibentuk dari adverbia tam 'di sana' dan $z$ des' 'di sini'. Adverbia tersebut merupakan adverbia lokatif, yang secara semantis menyatakan makna leksikal dasar tempat. Oleh sebab itu, adjektiva deadverbial tersebut menyatakan makna ruang berupa lokasi keberadaan. Walaupun adjektiva derivatif tersebut diartikan sama dengan adverbia, yakni di sana dan di sini, tetapi secara morfologis kata tersebut berkategori adjektiva yang dapat dilihat dari sufiks pembentuknya serta diperkuat oleh adanya fleksi pemarkah adjektival, seperti tampak pada tanda linguistis tercantum, sebagai penanda ciri morfologis berupa kategori gramatikal gender, jumlah, dan kasus. Pada (4), adjektiva deadverbial menunjukkan relasi konkordansi dengan nomina pravitel' 'penguasa' sehingga dapat ditentukan fungsi sintaktis adjektiva tersebut, yakni berfungsi atributif dalam konstruksi frasa. Makna ruang ini dapat diuji melalui parafrasa berikut, yaitu penguasa yang (berkedudukan) di sana. Sementara pada kalimat (5) On $z$ dešnij 'Dia di sini', adjektiva deadverbial tampak tidak mengatributi suatu benda. Walaupun konstruksi tersebut dapat saja, misalnya, dikatakan berasal dari On zdešnij celovek 'Dia (adalah) orang yang (ada) di sini' sehingga adjektiva deadverbial berfungsi atributif, namun secara struktural adjektiva deadverbial yang menyatakan makna ruang tersebut menduduki fungsi predikat terhadap subjek on 'dia'. Oleh sebab itu, adjektiva deadverbial ini dapat dikatakan memiliki fungsi predikatif pada kalimat tersebut. 


\subsection{Adjektiva Denominal dengan Prefiks Bermakna Ruang}

Telah dikemukakan pada bagian pendahuluan bahwa pada pembentukan adjektiva dapat terbentuk adjektiva bermakna ruang melalui prefiksasi dan konfiksasi.Namun pada dasarnya, makna ruang berupa lokasi dan arah ini berasal dari prefiks. Adapun prefiksyang memberikan nuansa makna ruang pada adjektiva ini adalah prefiks $z a$ - dengan makna 'di seberang', meždu'diantara', na-'di (atas bidang/permukaan)', nad-'di atas', po-'di dekat, sepanjang', pred-'di depan', pod-'di bawah, di dekat', pri-'dekat', vne-'di luar', vnutri-'di dalam', okolo-'di sekitar', cerez-'melalui', serta prefiks serapan trans'melalui' dan sub-'di bawah'(AN SSSR, TT; Belousov, et al, 1989: 96-98; Walgina, et al, 2002). Produktivitas prefiks dilihat dari penggunaan prefiks dalam suatu proses pembentukan kata. Prefiks-prefiks di atas umumnya merupakan prefiks yang produktif, yakni banyak digunakan dalam ragam bahasa tulis atau bahasa buku, serta dimanfaatkan untuk menyatakan istilah-istilah khusus seperti dalam bidang ilmu pengetahuan dan teknologi, politik, geografi, jurnalistik, seni, dan kesusastraan (AN SSSR, TT).

Perlu pula dikemukakan bahwa tampaknya, prefiks-prefiks ini memiliki

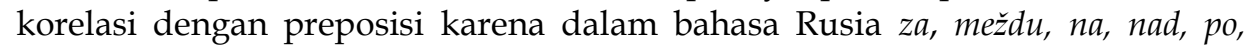
pred/pered, pod, pri, vne, vnutri, okolo, dan cerez merupakan preposisi. Satu preposisi dapat menyatakan satu makna atau lebih (Maksimov, 2010: 593). Preposisi-preposisi di atas di antaranya memiliki makna yang serupa dengan makna yang dinyatakan prefiks korelatifnya. Oleh karena itu, dapat dikatakan bahwa prefiks-prefiks ini merupakan bentuk alihan dari preposisi, yang pada fungsinya sebagai prefiks dalam suatu pembentukan kata, ditulis berangkai dengan dasar kata pembentuknya. Hal ini dipertegas pula oleh makna yang diungkapkan prefiks-prefiks tersebut, yang menunjukkan kesamaan dengan makna preposisi. Makna preposisi-preposisi ini dapat dilihat dalam uraian Maksimov, et al (2010: 595-597).

Sebagai bahan kajian, di bawah ini merupakan contoh data berupa kalimat yang di dalamnya terdapat adjektiva dengan beberapa prefiks bermakna ruang.

6) Za recnyj požar vozle recki Borovoj razgoralsja neskol'ko dnej. seberang sungai kebakaran dekat sungai Borova menyala beberapa hari

Adj.m.t.nom N.m.t.nom

(Viktor Astafiyev.Poslednij Poklon. 1968-1991. Dalam Korpus Nasional Bahasa Rusia)

'Api di seberang sungai, dekat sungai kecil Borova, menyala selama beberapa hari.'

7) On sumel sdelat' mobil'nuyu mežkontinental'nuju raketu. dia berhasil membuat mobile antar benua roket Adj.f.t.akN.f.t.ak

(Nikita Khrushchev. Vospominanija. 1971. Dalam Korpus Nasional Bahasa Rusia) 
'Dia berhasil membuat peluru kendali antarbenua.'

8) Nastol'naja lampa tusklo osveščala komnatu.

atas meja lampu redup menerangi ruangan

Adj.f.t.nomN.f.t.nom

(Vitaliy Gubarev. Troe na Ostrove.1950-1960.Dalam Korpus Nasional

Bahasa Rusia)

'Lampu meja dengan redup menerangi ruangan.'

9) Nadbrovnye morščiny Prohora rezko zadvigalis'.

atas alis lipatan Prokhortajam bergerak

Adj.j.nomN.j.nom

(V. Y. Shishkov. Ugrjum-reka.1913-1932. Dalam Korpus Nasional

Bahasa Rusia)

'Lipatan-lipatan di atas alis Prokhor berkerut tajam.'

Pada empat kalimat data di atas terdapat adjektiva yang menyatakan makna ruang, yaitu zarecnyj, mežkontinental'nuju, nastol'naja,dan nadbrovnye, yang dibentuk dari dasar nomina reka 'sungai', kontinent 'benua', stol 'meja', dan brov' 'alis' dengan penambahan sufiks - $n$ - dan fleksi pembentuk adjektiva. Pembubuhan prefiks $z a-$ 'di seberang', mež-(variandari meždu-)'diantara',na- 'di', dan nad- 'di atas' pada dasar adjektiva ini lah yang secara semantis memberikannuansa makna ruang pada adjektiva bentuk turunannya. Keempat adjektiva dalam kalimat tersebut berfungsi atributif, yaitu menjelaskan ciri maujud yang dinyatakan oleh nomina, yakni požar'kebakaran/api', raket(u) 'roket', lampa 'lampu', dan morščin(y)'lipatan', yang ditunjukkan pula oleh adanya konkordansi kategori gramatikal gender, jumlah, dan kasus antara adjektiva dengan nomina,sebagaimana dapat dilihat pada pemarkah linguistis yang tercantum di bawah frasa-frasa tersebut. Ciri sebagai atributyang diungkapkan oleh adjektiva ini menyatakan makna tempat, lokasi, keberadaan, yang melalui parafrasa berikut dapat terlihat jelas makna ruang yang disandang adjektiva ini, yaitu: kebakaran yang (terjadi) di seberang sungai pada (6), roket yang (dapat melintas) antarbenua pada (7),lampu yang (ada) di atas meja pada (8), dan lipatan-lipatan yang (ada) di atas alis pada (9). Keempat prefiks tersebut merupakan prefiks produktif yang sering digunakan dalam ragam bahasa tulis dan banyak digunakan untuk menamai istilah khusus seperti istilah dalam ilmu pengetahuan teknologi dan istilah georafis untuk prefiks $z a-$, istilah dalam ilmu pengetahuan teknologi dan politik untuk prefiks mež-, dan istilah-istilah khusus untuk prefiks na- dan nad- (AN SSSR, TT).

Adjektiva derivatif yang bermakna ruang lainnya, yang diantaranya memiliki makna yang dekat, dapat dicermati pada contoh data di bawah ini.

10) Podorožnye kusty stojat rovno i kruglo.

di jalanan semak berdiri datar dan bulat

Adj.j.nom N.j.nom

(L. M. Leonov. Barsuki. 1924. Dalam Korpus Nasional Bahasa Rusia)

'Semak-semak di sepanjang jalan tumbuh rata dan rimbun.' 
11) Mašina v"ehala v pyl'nyj primorskij gorodok Limassol.

mobil pergi ke berdebu dekat laut kota kecil Limassol

Adj.m.akN.m.t.ak

(Semen Daniljuk. Biznes-klass. 2003. Dalam Korpus Nasional Bahasa

Rusia)

'Mobil melaju ke Limassol, kota kecil berdebu dekat laut.'

12) Ja stal vsmatrivat' sya iz moego zabytogo ugla vchernotu nochi, kak v

saya mulai memandang dari saya terlupakan sudut ke gelapnya malam seperti ke

okololunnyj svet.

dekat bulan cahaya

Adj.m.t.ak N.m.t.ak

(Vladimir Makanin. Andegraund, ili Geroy Nashego Vremeni. 1996-1997.

Dalam Korpus Nasional Bahasa Rusia)

'Saya mulai memandang dari sudut yang saya lupakan, pada gelapnya malam, seperti pada cahaya sekitar bulan.'

Pada tiga kalimat di atas, adjektiva yang menyatakan makna ruang, yaitu podorožnye, primorskij, dan okololunnyj, dibentuk dari dasar nomina doroga 'jalan', more 'laut', dan luna' 'bulan' dengan penambahan sufiks - $n$ - dan -sk- serta fleksi pembentuk adjektiva. Makna ruang secara semantis berasal dari prefiks yang dibubuhkan pada dasar adjektiva tersebut, yakni po-'di sepanjang', pri- dan okoloyang bermakna leksikal dasar 'dekat', tetapiokolo lebih spesifik merujuk pada makna 'sekitar, seputar(an)'. Adjektiva bermakna ruang pada ketiga kalimat tersebut menduduki fungsi atributif,yakni memberikan keterangan sebagai ciri maujud dari nominakust (y)'semak-semak', gorodok 'kota kecil', dan svet'cahaya'. Kecuali itu, ditunjukkan pula oleh adanya konkordansi kategori gramatikal gender, jumlah, dan kasus pada adjektiva dan nomina,sebagaimanatampak pada pemarkah-pemarkah linguistis tercantum. Untuk menguji makna ruang pada adjketiva yang menerangkan ciri berupa makna lokasi atau tempat keberadaan ini, dapat dilakukan parafrasa berikut: semak-semak yang (ada/tumbuh) di sepanjang jalan untuk data (10), rumah kecil yang (ada/berlokasi) di dekat laut (tepi pantai) untuk data (11), dan cahaya yang (ada/bersinar) di sekitar bulan untuk data (12). Ketiga prefiks pada contoh data di atas adalah prefiks yang produktif digunakan, yakni prefiks po- banyak dimanfaatkan dalam penyebutan istilah geografis, prefiks pri- produktif digunakan dalam istilah ilmu pengetahuan, dan prefiks okolo- banyak digunakan untuk menyebut istilahistilah teknik dan dalam ragam tulis jurnalistik (AN SSSR, TT).

Di bawah ini adalah contoh adjektiva bermakna ruang dengan prefiks serapan, namun produktif digunakan pada pembentukan adjektiva bahasa Rusia. 
13) Rakety, transkontinental'nye ekspressy, vertolety - ponjatno: ekonomija vremeni.

roket antarbenua ekspres helikopter dimengerti ekonomi waktu Adj.j.nom N.j.nom

(Yevgeniy Veltistov. Glotok Solntsa. 1967. Dalam Korpus Nasional Bahasa Rusia)

'Roket, kereta ekspres lintas benua, helikopter - dapat dimengerti: menghemat waktu.'

Adjektiva pada kalimat data (13), yakni transkontinental'nye, adalah adjektiva bermakna ruang yang berarti 'antarbenua'. Makna ruang tersebut secara semantis diwujudkan melalui prefiks serapan trans- 'melalui, melintasi' pada dasar kata pembentuknya, yakni nomina kontinent'benua', dengan penambahan sufiks - $n$ - dan fleksi pemarkah adjektiva. Pada kalimat data di atas, adjektiva bermakna ruang iniberfungsi atributif,yaitu menerangkan ciri bendayang diwujudkan oleh nomina ekspress(y)'(kereta) ekspres', yang juga tampak dari adanya konkordansi kategori gramatikal gender, jumlah, dan kasus antara adjektiva dengan nomina, seperti dapat dilihat pada pemarkah-pemarkah linguistis tercantum. Selain dari makna leksikal dasar yang dikandung prefiks trans-, keterangan berupa ciri benda yang menyatakan makna tempat ini dapat ditelusuri pula melalui parafrasa, yakni kereta ekspres yang (dapat beroperasi di/pada) antar/lintas benua. Prefiks ini tampaknya memiliki kesinoniman dengan prefiks mež- pada adjektiva dalam kalimat data (7), yakni mežkontinental'nuju'antarbenua'. Hanya saja, prefiks trans- merupakan prefiks serapan. Namun walaupun demikian, prefiks serapan ini merupakan prefiks yang produktif digunakan dalam pembentukan adjektiva bahasa Rusia, khususnya banyak dimanfaatkan dalam membuat sebutan atau penamaan yang berkaitan dengan bidang geografi (AN SSSR, TT).

\section{PENUTUP}

Dari hasil pembahasan dapat disimpulkan bahwa pada adjektiva bahasa Rusia terdapat adjektiva yang menyatakan makna ruang yang merujuk pada tempat berupa lokasi, keberadaan, kedudukan, dan arah dari atau menuju. Adjektiva ini merupakan adjektiva derivatif yang dibentuk dari kategori lain, yakni nomina dan adverbia, melalui proses morfologis sufiksasi dan pembubuhan fleksi adjektival sebagai pemarkah kategori gramatikal gender, jumlah, dan kasus yang merupakan ciri morfologis adjektiva. Melalui kategori gramatikal ini pula dapat ditentukan perilaku sintaktis adjektiva bermakna ruang yang umumnya menunjukkan fungsi atributif melalui relasi konkordansinya dengan nomina sebagai benda/maujud yang diterangkan cirinya. Secara semantis, makna ruang yang diungkapkan oleh adjektiva dapat berasal dari kata pembentuknya, yakni nomina (adjektiva denominal) dan adverbia (adjektiva deadverbial) yang mengandung makna leksikal dasar lokatif. Hal ini tampak lebih jelas pada suatu konstruksi frasa yang pada antarunsurnya menyatakan relasi makna lokatif. Di samping itu, makna ruang pada adjektiva juga secara luas dinyatakan melalui berbagai prefiks yang digabungkan dengan dasar kata pembentuk adjektiva, yakni berupa nomina 
(adjektiva denominal). Prefiks ini pada dasarnya berkorelasi dengan preposisi bermakna lokatif dan direktif, sehingga dapat dikatakan terjadi alih bentuk dan fungsi dari preposisi ke prefiks, tetapi dengan makna serupa. Pembedaan adapadacara penulisannya, yaitu prefiks ditulis berangkai dengan dasar kata pembentuk adjektiva. Prefiks-prefiks bermakna ruang ini produktif digunakan, terutama dalam ragam tulis serta untuk menyatakan istilah-istilah khusus di bidang ilmu pengetahuan.

Pengamatan ini lebih terfokus pada makna ruang yang dinyatakan oleh adjektiva melalui makna leksikal dasar kategori kata pembentuknya serta prefiks. Sementara proses pembentukan adjektiva derivatif ini melibatkan berbagai prefiks dengan varian-variannya, yang antara lain dapat berkaitan secara morfofonemis. Begitu pula dengan berbagai sufiks dan varian-variannya. Kiranya,masih perlu penelusuran yanglebih mendalam terkait proses pembentukan adjektiva ini, umtuk mendapatkan pola pembentukannya.

\section{DAFTAR PUSTAKA}

Akademija Nauk (AN) SSSR. TT. Russkaja Grammatika. Institut Russkogo Jazyka. Diakses dari rusgram.narod.ru. tanggal 21 Oktober 2019.

Belousov, V.N., Kovtunova, I.I., Krucinina, I.N., Lopatin, V.V., Ljapon, M.V., Plotnikova, V.A., ..., Shvedova, N.Yu. 1989. Kratkaja Russkaja Grammatika. Moskwa: Russkij Jazyk.

Djajasudarma, T. Fatimah. 1993. Metode Linguistik. Ancangan Metode Penelitian dan Kajian. Bandung: Eresco.

Dudnikov, A.V., Arbuzova, A.I., Vorozhvitskaja, I.I. 2001. Russkij Jazyk. Moskwa: Vyshaja Shkola.

Karyaningsih, T.Y. 2018a. "Relasi Sintaktis Antarkomponen pada Frasa Nomina Bahasa Rusia." dalam JurnalMetahumaniora. Volume 8. Nomor 1. hal. 18-28.

Karyaningsih, T.Y. 2018b. “Frasa Nomina Endosentris Atributif Berpewatas Adjektiva dalam Bahasa Rusia dan Bahasa Indonesia: Aplikasi Analisis Kontrastif dalam Penerjemahan."dalam Jurnal Linguistik Terapan Politeknik Negeri Malang. Volume 8. Nomor 1. hal. 1-20. Diakses dari http://jlt-polinema.org tanggal 4 Agustus 2018.

Korpus Nasional Bahasa Rusia. Diakses dariwww.ruscorpora.ru. tanggal 17November 2019.

Maksimov, V.I., Akimova, G.N., Alatortseva, S.I., Belousov, V.N., Bulanin, L.L., Glovinskaja, M.Ya., ..., Onipenko, N.K. 2010. Sovremennyj Russkij Literaturnyj Jazyk. Moskwa: Iurait.

Miletova, E.V. 2008. “O Morfologiceskih, Sintaksiceskih i Semanticeskih Kharakteristikah Imen Prilagatel'nyh i Slov Kategorii Sostojanija v Anglijskom i Russkom Jazykah."dalam Jurnal Obščestvennye $i$ Gumanitarnye Nauki. hlm.195-201. Diakses dari cyberleninka.ru. tanggal 8 Oktober 2019. 
Sharipova, V.M. 2007. “Skrytaja Predikativnost' Atributivnyh Struktur.” Dalam Jurnal Vesnik Bashkirskogo Universiteta. Volume 12. Nomor 4. hlm. 110111.

Sinkevich, D.A. 2010. “Atributivnye Konstruktsii v Sovremennoj Lingvistike: Problemy Opredelenija i Analiza." Dalam JurnalAktualnye Voprosy Sovremennoj Nauki. Nomor 12. hlm. 239-248. Diakses dari http:/ / elibrary.ru. tanggal 20 September 2019.

Sudaryanto. 2015. Metode dan Aneka Teknik Analisis Bahasa. Yogyakarta: Sanata Dharma University Press.

Walgina, N.S., Rozental', D.E., Fomina, M.I. 2002. Sovremennyj Russkij Jazyk. Moskwa: Golos. Diakses dari https://nashol.com. tanggal 21 Oktober 2019.

\section{DAFTAR SINGKATAN}

$\begin{array}{ll}\text { Adj } & \text { adjektiva } \\ \text { ak } & \text { akusatif } \\ \mathrm{f} & \text { feminin } \\ \mathrm{j} & \text { jamak } \\ \mathrm{m} & \text { maskulin }\end{array}$

$\begin{array}{ll}\mathrm{N} & \text { nomina } \\ \mathrm{n} & \text { netral } \\ \text { nom } & \text { nominatif } \\ \mathrm{t} & \text { tunggal }\end{array}$

